\title{
Several anthropometric predictors of cardiovascular disease in central Slovakian adults: socioeconomic and educational differences
}

\author{
Hujova Z, Rostakova K \\ Department of Biology, Faculty of Science, Matej Bel University, Banska Bystrica, Slovakia. \\ zuzana.hujova@gmail.com
}

\begin{abstract}
Background: Slovak inhabitants are considered at high risk of cardiovascular disease (CVD). Objective: The aim of the study was to describe the social and educational differences in relation to anthropometric CVD risk factors among central Slovakian adults.

Participants: The study population consisted of 100 probands from the central Slovakian region of Orava (50 males and 50 females). According to their social background they were classified as those with high (15\%), average $(71 \%)$ or low socioeconomic status (14\%). According to their education they were classified as those having completed only primary education (15\%) secondary education graduates $(69 \%)$ or university graduates $(16 \%)$. Methods: Anthropometric measurements, including weight, height, waist and hip circumference, triceps and subscapular skinfold were used to calculate body mass index (BMI), waist-to-hip ratio (WHR) and percentage body fat. Measured blood pressure (BP) was used to classify for hypertension.

Results: The probands with high socioeconomic status show the highest means of body fat percentage (24.53 $\pm 3.11 \%$ ) and blood pressure (with $53 \%$ prevalence of hypertension and $60 \%$ of stress); the population with low socioeconomic status had the highest prevalence of cigarette smoking $(57.1 \%)$, physical inactivity $(64.3 \%)$ and CVD family history $(78.6 \%)$. The highest means of BMI $\left(25.48 \pm 3.26 \mathrm{~kg} / \mathrm{m}^{2}\right)$ were determined in participants with university education (they also show the highest stress rate at $46.7 \%$ ). The population with primary education show the highest means of WHR $(0.89 \pm 0.13)$ and SBP $(138.44 \pm 19.64 \mathrm{mmHg})$, and the highest prevalence of hypertension (56.3\%), physical inactivity (62.5\%) and CVD family history $(81.3 \%)$.

Conclusion: The results of the study should lead to improving the prevention of CVD risk predictors, especially in adults with low socioeconomic status and primary education (Tab. 3, Ref. 29). Full Text in PDF www.elis.sk. Key words: anthropometry, obesity, hypertension, adults, social, differences, education, lifestyle.
\end{abstract}

\begin{abstract}
Abbreviations: CVD - cardiovascular disease; $\mathrm{BF}$ - body fat percentage; BMI - body mass index; WHR - waist-to-hip ratio; BP - blood pressure; sBP - systolic blood pressure; dBP - diastolic blood pressure; RF - risk factors.

Health problems are potentially influenced by the socioeconomic status (SES) (1). Cardiovascular disease (CVD) remains the leading cause of death, especially among the socially deprived (2). SES is consistently inversely associated with CVD risk factors (including excess weight, hypertension, unfavourable lipid levels, diabetes, physical inactivity, and cigarette smoking); (3); at the same time it is an important factor in their progression (4).

The gap in the occurrence of CVD between higher and lower socioeconomic groups is getting wider (5). Socioeconomic distribution of body fat percentage varies with age and sex (6).
\end{abstract}

Department of Biology, Faculty of Science, Matej Bel University, Banska Bystrica, Slovakia

Address for correspondence: Z. Hujova, MD, Dept of Biology, Faculty of Education, Trnava University in Trnava, Priemyselna 4, SK-917 00 Trnava, Slovakia.

Phone: +421.33 .5514618$
Differences in CVD risk between probands from urban and rural areas were also demonstrated. Urban participants were taller, heavier, and had higher BMI values than their rural counterparts (7), which is primarily influenced by SES (urbanization influences, environmental and behavioural mechanisms).

Further notable phenomena such as education seem a particularly strong indicator in evaluating the association between SES and CVD risk factors. Better educated and wealthier individuals have sometimes higher rates of metabolic syndrome (8). However, less educated persons are generally more likely to display other risk factors (smoking, sedentary lifestyle, high fat diet, overweight) (9).

Obesity is more accepted among lower-educated people (10), and in adults it is a significant determinant for high blood pressure and other CVD risk factors with serious consequences (11).

There is a lack of understanding why CVD risk is associated with SES and education level in adults. To our knowledge, there has been no previous study set out to examine the situation among Slovaks.

The aim of the study is to provide available data as to how different social and educational levels relate to anthropometric CVD risk indicators such as percentage body fat (BF), body mass index (BMI), waist-to-hip ratio (WHR) and blood pressure (BP) as well as to exogenous conditions in central Slovakian males and females. 


\section{Study population and methods}

The study population consisted of 100 participants (50 males and 50 females) from central Slovakia (namely from Orava region). According to their social background they were classified as those with high (15\%), average (71\%) or low socioeconomic status (14\%). According to their education they were classified as those having completed only primary education (15\%) secondary education graduates $(69 \%)$ or university graduates $(16 \%)$.

In 2009-2010, the examined population was randomly selected to represent the healthy population. The information on lifestyle (cigarette smoking, stress, physical activity) was obtained from a questionnaire. Only non-lipid and anthropometric CVD risk factors were determined: BF, BMI, WHR, sBP and dBP.

Skin folds were measured at triceps and subscapula using a standard caliper. Calculations of body fat percentage were performed with standard equations. Anthropometric measurements (height and weight) were taken using a stadiometer. BMI used to assess the obesity prevalence $\left(\mathrm{BMI}>25 \mathrm{~kg} / \mathrm{m}^{2}\right)$, was calculated as a quotient of weight and squared height in meters $\left(\mathrm{kg} . \mathrm{m}^{-2}\right)$. WHR was calculated as a derived waist-to-hip circumference. Waist circumference was measured in the middle between the arch of the 10 th rib and the top of crista iliaca (evaluation of risk WHR $>90$ for male and WHR $>85$ for female).

Blood pressure was measured twice from the right arm using a standard mercury sphygmomanometer with the subject in sitting position. Hypertension was defined as $\mathrm{sBP}>140 \mathrm{mmHg}$, and $\mathrm{dBP}>90 \mathrm{mmHg}$,

The results are expressed as mean $\pm \mathrm{SD}$. Normality was checked with the Kolmogorov-Smirnov test. When the variables were not normally distributed, we used the Kruskal-Wallis test and evaluated the variables' distribution in socioeconomic and education-related groups. The values of $\mathrm{p}<0.05$ were considered statistically significant. The Fisher exact test was used to evaluate the relationship between CVD risk factors and lifestyle. Statistical analyses were performed using the SPSS System software package.

\section{Results}

\section{Characteristics of study population}

Data on CVD risk predictors in adults $(\mathrm{n}=100)$ divided according to socioeconomic groups are given in Table 1.

The highest means of BF and BP (53\% prevalence of hypertension and $60 \%$ of stress) were determined in the high-SES population.

Interestingly, the lowest means of BF and BMI were recorded in the low-SES group, although they also had the highest prevalence of cigarette smoking, low physical fitness and CVD family history.

The highest risk values of BF, BMI and WHR were found in participants with middle SES (where the means of BMI were above limit).

The mean values of sBP were above the acceptable range in participants with high SES.
Tab. 1. Socioeconomic level related to anthropometric values and lifestyle in central Slovakian adults.

\begin{tabular}{|c|c|c|c|}
\hline & $\begin{array}{l}\text { Participants } \\
\text { with high } \\
\text { SES }(n=15)\end{array}$ & $\begin{array}{l}\text { Participants } \\
\text { with middle } \\
\text { SES }(n=71)\end{array}$ & $\begin{array}{l}\text { Participants } \\
\text { with low } \\
\text { SES }(N=14)\end{array}$ \\
\hline $\begin{array}{l}\% \text { body fat } \\
>20 \% \text { for males }(\%)\end{array}$ & $24.53 \pm 3.11$ & $24.21 \pm 5.36$ & $20.03 \pm 5.38$ \\
\hline$>30 \%$ for females $(\%)$ & 33.3 & 54.9 & 28.6 \\
\hline BMI $\left(\mathrm{kg} / \mathrm{m}^{2}\right)$ & $24.47 \pm 2.79$ & $25.52 \pm 4.43$ & $22.58 \pm 3.25$ \\
\hline Above $25 \mathrm{~kg} / \mathrm{m}^{2}(\%)$ & 33.3 & 47.9 & 21.4 \\
\hline $\begin{array}{l}\text { WHR } \\
>0.9 \text { for males }(\%)\end{array}$ & $0.81 \pm 0.09$ & $0.88 \pm 0.09$ & $0.86 \pm 0.08$ \\
\hline$>0.85$ for females $(\%)$ & 20 & 52.1 & 28.6 \\
\hline sBP (mmHg) & $143.33 \pm 18.77$ & $135.85 \pm 19.89$ & $137.86 \pm 23.02$ \\
\hline dBP (mmHg) & $88.67 \pm 11.41$ & $84.37 \pm 13.99$ & $85 . \pm 14.94$ \\
\hline Hypertension (\%) & 53.3 & 33.8 & 42.9 \\
\hline Cigarette smoking & $26.7 \%$ & $21.1 \%$ & $57.1 \%$ \\
\hline CVD family history & $66.7 \%$ & $64.8 \%$ & $78.6 \%$ \\
\hline Stress & $60 \%$ & $19.7 \%$ & $14.3 \%$ \\
\hline Physical Inactivity & $60 \%$ & $57.7 \%$ & $64.3 \%$ \\
\hline Age & $38.53 \pm 16.36$ & $41.28 \pm 17.59$ & $36.36 \pm 18.02$ \\
\hline
\end{tabular}

Tab. 2. Educational level related to anthropometric values and lifestyle in central Slovakian adults.

\begin{tabular}{lccc}
\hline & $\begin{array}{c}\text { Population } \\
\text { with university } \\
\text { education } \\
(\mathrm{n}=15)\end{array}$ & $\begin{array}{c}\text { Population } \\
\text { with secondary } \\
\text { education } \\
(\mathrm{n}=69)\end{array}$ & $\begin{array}{c}\text { Population } \\
\text { with primary } \\
\text { education } \\
(\mathrm{n}=16)\end{array}$ \\
\hline \% body fat & $23.53 \pm 2.69$ & $\mathbf{2 4 . 0 8} \pm \mathbf{4 . 4 7}$ & $22.09 \pm 9.03$ \\
$>20 \%$ for males $(\%)$ & & & \\
$>30 \%$ for females $(\%)$ & 33.3 & $\mathbf{5 3 . 6}$ & 37.5 \\
\hline BMI $\left(\mathbf{k g} / \mathbf{m}^{2}\right)$ & $\mathbf{2 5 . 4 8} \pm \mathbf{3 . 2 6}$ & $24.94 \pm 3.99$ & $24.52 \pm 5.69$ \\
$>25 \mathrm{~kg} / \mathrm{m}^{2}$ & $\mathbf{4 6 . 7}$ & 40.6 & 43.8 \\
\hline WHR & $0.83 \pm 0.09$ & $0.87 \pm 0.09$ & $\mathbf{0 . 8 9} \pm \mathbf{0 . 1 3}$ \\
$>0.9$ for males $(\%)$ & & & 37.5 \\
$>0.85$ for females $(\%)$ & 33.3 & $\mathbf{4 7 . 8}$ & $\mathbf{1 3 8 . 4 4} \pm \mathbf{1 9 . 6 4}$ \\
\hline sBP $(\mathbf{m m H g})$ & $131.67 \pm 12.77$ & $138.19 \pm 21.56$ & $\mathbf{1 3}$ \\
dBP $(\mathbf{m m H g})$ & $83.33 \pm 10.29$ & $\mathbf{8 6 . 5 2} \pm \mathbf{1 4 . 4 8}$ & $80.63 \pm 12.63$ \\
\hline Hypertension $(\%)$ & 33.3 & 34.8 & $\mathbf{5 6 . 3}$ \\
Cigarette smoking & $26.7 \%$ & $\mathbf{2 9} \%$ & $18.8 \%$ \\
CVD family history & $53.3 \%$ & $66.7 \%$ & $\mathbf{8 1 . 3 \%}$ \\
Stress & $\mathbf{4 6 . 7 \%}$ & $26.1 \%$ & - \\
Physical Inactivity & $53.3 \%$ & $59.4 \%$ & $\mathbf{6 2 . 5 \%}$ \\
Age & $30.87 \pm 10.55$ & $38.64 \pm 16.28$ & $55.56 \pm 18.52$ \\
\hline mean \pm SD & & &
\end{tabular}

mean \pm SD

The highest means of BMI (with highest percentage of risk values) were calculated in the population with university education while, which shows the highest prevalence of stress at $46.7 \%$.

On the other hand, the highest means of WHR and sBP were determined in the participants with primary education. They also show the highest rates of hypertension $(56.3 \%)$, physical inactivity $(62.5 \%)$ and CVD family history $(81.3 \%)$.

The anthropometric and lifestyle parameters in relation to education level in central Slovakian adults $(n=100)$ are shown in Table 2 .

The highest means of BMI (with highest percentage of risk values) were calculated in the population with university educa- 
Tab. 3. Tested socioeconomic and educational differences related to anthropometric values (Kruskal-Wallis test).

\begin{tabular}{lccccc}
\hline & BF & WHR & BMI & sBP & dBP \\
\hline $\mathrm{p}$ (socioeconomic differences) & 0.03 & 0.028 & 0.04 & $\mathrm{~ns}$ & $\mathrm{~ns}$ \\
$\mathrm{p}$ (educational differences) & $\mathrm{ns}$ & $\mathrm{ns}$ & $\mathrm{ns}$ & $\mathrm{ns}$ & $\mathrm{ns}$ \\
\hline
\end{tabular}

$* \mathrm{p}<0.05 ; \mathrm{ns}-$ non-significant

tion who at the same time show the highest prevalence of stress, namely in $46.7 \%$.

On the other hand, the highest means of WHR and sBP were determined in the participants with primary education. They also show the highest rates of hypertension $(56.3 \%)$, physical inactivity $(62.5 \%)$ and CVD family history $(81.3 \%)$.

The adults with secondary education had the highest means of $\mathrm{BF}, \mathrm{dBP}$ (and high-risk $\mathrm{dBP}$ ) and WHR. They show a $29 \%$ prevalence of cigarette smoking.

A nonparametric Kruskal-Wallis test showed statistically significant differences $(\mathrm{p}<0.05)$ in anthropometric values in relation to different socioeconomic levels (Tab. 3).

\section{Discussion}

The probands with high socioeconomic status show the highest means of BF $(24.53 \pm 3.11 \%)$ and BP (with $53 \%$ prevalence of hypertension and $60 \%$ of stress), and the examined population with low socioeconomic status had the highest prevalence of cigarette smoking (57.1\%), physical inactivity (64.3\%) and CVD family history $(78.6 \%)$. The highest means of BMI $\left(25.48 \pm 3.26 \mathrm{~kg} / \mathrm{m}^{2}\right.$; values above limit) were determined in probands with university education (they show the highest stress rate, $46.7 \%$ ). The examined population with primary education had the highest means of WHR $(0.89 \pm 0.13)$ and sBP $(138.44 \pm 19.64 \mathrm{mmHg})$, and the highest prevalence of hypertension $(56.3 \%)$, physical inactivity $(62.5 \%)$ and CVD family history $(81.3 \%)$.

Overall, Slovakia leads the European Union in CVD risk factors (prevalence of overweight, obesity and hypertension, lack of physical activity and unfavourable nutrition (12).

Although some data show that populations with socioeconomic disadvantage have lower prevalence of obesity, dyslipidemia, hypertension and hyperglycemia (13), low SES usually correlates with higher risk of CVD and high-risk lifestyle (similarly, our low-SES probands show higher prevalence of cigarette smoking and physical inactivity).

The Slovak low-SES population, for example the majority of Gypsy ethnic population, is known to have a higher prevalence of obesity, hypertension and worse environmental conditions (cigarette smoking, sedentary behaviour, alcohol consumption, etc.). The authors of these studies conclude that programmes to reduce the risk predictors should focus on lower-SES communities (14), despite the fact that as disadvantaged persons with low SES they may be less able or willing to make behavioural changes in response to preventive health services (15).

High SES is not always related to lower risk of CVD. Our examined population with high SES shows the highest means of percentage body fat and is more hypertensive.
Our study confirms a significant association of SES with body fat, WHR and BMI.

There are disparities in the prevalence of overweight and obesity according to SES. Usually women of lower SES and lower education are approximately $50 \%$ more likely to be obese than those of higher SES. Men are about equally likely to be obese regardless of their socioeconomic status (16). Epidemiologic studies indicated an inverse association of SES and CVD risk factors in urban populations in China (17).

Socioeconomic conditions can contribute to low birth weight and poor fetal growth which later in life negatively affect the central fat distribution. BMI and WHR and constitutes an increased risk for several adult degenerative diseases (18). Inadequate nutrition in early childhood (more common among socially disadvantaged populations) may serve to potentiate adult obesity-related disease (19).

Girls with higher SES consume fewer calories and may expend more calories (due to being more physically active) than other girls. Girls from lower SES backgrounds may consume more fat on average. In Swedish adolescents it was found that regular exercise was more common among girls whose father had a high level of education (20).

As opposed to the latter, the elderly population with higher SES shows worse nutritional behaviours playing a significant role in worsening their CVD risks and increasing the mortality rate (Costa Rican Study, 21). It will prove useful to longitudinally observe the development of CVD risk factors related to SES in different age populations in Slovakia.

Interestingly, the population with university education shows higher means of BMI (and obesity), in comparison with the populations with lower degrees of education. In a CARDIA study, Caucasian women with secondary or lower education had a significantly higher total body fat and BMI compared to white women with higher educational levels. Differences by educational level were less pronounced among men (22).

As was expected, the population with primary education has the highest prevalence of hypertension, highest means of WHR, lowest physical fitness and highest prevalence of CVD family history.

Comparing the findings of the present study with those of Krajčovičová-Kudláčková (23), CVD risk is similar to that of the Slovak Gypsy population known to be poorly educated (associated with their poverty) and to be having more CVD risk predictors in comparison to the general population with a relatively higher degree of education.

The worst results with highest rates of CVD risk factors were determined in the population with the least education (24). Obesity is especially prevalent in working-class people with a lower degree of education. Blood pressure was inversely associated with the level of education in the urban population. Educational level was inversely associated with mean values of BP and BMI for women and with cigarette smoking for both sexes. Men who had less than twelve years of education were 1.6 times more likely to be current smokers compared with those most educated. Men with the lowest incomes were 1.4 
times more likely to be smokers compared to those with highest incomes (25).

The association between the education level and CVD-related risk factors is in accordance with reported findings from other studies. In a study of Slovak Gypsy population, $54 \%$ of Gypsy people vs $3 \%$ of the general population had completed only the primary education. Low educational level is generally connected with lower knowledge about optimal nutrition (26). It is important to focus the primary prevention especially on people with low education.

Hypertension and body fat in the least educated subjects may correlate with their nutrition. People with only primary education tend towards high-calorie diets generally containing more animal lipids and less fruit, vegetables and fibre. More educated Slovaks consume more vegetables than those less educated (27).

Epidemiologists report an increased CVD risk in the population with only primary education compared to graduates of higher education. Education is one of the most significant determining factors of cigarette smoking, obesity, hypertension and CVD.

Highly educated people experience an earlier onset of CVD risk factors and display a faster decline compared with less educated people (28). Other studies have established a strong relationship between the number of parental years of education and childhood obesity (29).

Unlike findings in other populations in which education mitigates the CVD risks, the university graduates participating in our study show relatively high BMI and obesity. We hypothesize a future reduction in BMI among women and those of higher social classes.

The poor health status of the examined population is reflected by low degree of education and SES. There is a correlation between cigarette smoking and degree of education - those with only primary education smoked the most. In our study, cigarette smoking and physical inactivity was alarmingly shown in more than half of participants with low SES and only primary education.

Although the interpretation of results obtained from our research is limited by the relatively small number of participants (low and high SES level, primary and university education), CVD risk was heterogeneous in different socioeconomic and educational groups in this central Slovakian population.

Although there are many studies of CVD risk predictors in adults, few take socioeconomic and educational differences into account. Our results indicate the importance of CVD prevention with respect to these significant socioeconomic and educational determinants.

Without improving the education, prevention of cigarette smoking, and increasing the physical activity, the Slovaks will be exposed to risks which represent multidimensional dangers in combination, and can lead to a dramatic increase in CVD morbidity and mortality.

\section{References}

1. Viewing VR, Johnston ChH, Lanier JO, Fernandez A, Pandurangi AK. Correlation beteen High Risk Obesity Groups and Low Socioeconomic Status in School Children. South Med Ass 2007; 100 (1): 8-13.
2. Yu Z, Nissinen A, Vartiainen E, Song G, Guo Z, Tian H. Changes in cardiovascular risk factors in different socioeconomic groups: seven year trends in a Chinese urban population. J Epid Comm Health 2000; 54 (9): 692-696.

3. Govil SR, Weidner G, Merritt-Worden T, Ornish D. Socioeconomic Status and Impovements in Lifestyle Coronary Risk Factors and Quality of Life: The Multisite Cardiac Lifestyle Intervention Program. Res Pract 2009; 99 (7): 1263-1270.

4. Yu Z, Nissinen A, Vartiainen E, Hu G, Tian H, Guo Z. Socio-economic status and serum lipids: A cross-sectional study in a Chinese urban population. J Clin Epidem 2002; 55: 143-149.

5. Yu Z, Nissinen A, Vartianinen E, Song G, Guo Z, Zheng G, Tuomilehto J, Tian H. Association between socioeconomic status and cardiovascular risk factors in an urban population in China. Bulletin of WHO 2000; 78: 1296-1305.

6. Booth ML, Macaskill P, Lazarus R, Baur LA. Sociodemographic distribution of measures of body fatness among children and adolescetns in New South Wales, Australia. Int J Obesity 1999; 23: 456-462.

7. Manios Y, Magkos F, Christakis G, Kafatos AG. Twenty - year dynamics in adiposity and blood lipids of Greek children: Regional differences in Crete persist. Acta Pediat 2005; 94: 859-865.

8. Rosero-Bixby, L, Dow, WH. Surprising SES Gradients in Mortality, Health and Biomarkers in a Latin American Population of Adults. J Geront 2009; 64B: 105-117.

9. Govil SR, Weidner G, Merritt-Worden T, Ornish D. Socioeconomic Status and Impovements in Lifestyle Coronary Risk Factors and Quality of Life: The Multisite Cardiac Lifestyle Intervention Program. Res Pract 2009; 99 (7): 1263-1270.

10. Kollár J. Obezita, primárny rizikový faktor. I. Čast'. Ateroskleróza, 2001; 5 (3): 152-169.

11. Williams CHL, Stroino B, Bollella M, Brotanek J. Body Size and Cardiovascular Risk Factors in a Preschool Population. Prev Cardiol 2004; 7: 116-121.

12. Jurkovičová J, Štefániková Z, Ševčíková L, Sootová L', Ághová L. Vybrané biomarkery zdravotného stavu ako odraz životného štýlu slovenskej populácie. Voj Zdrav Listy 2003; 72 (4): 160-163.

13. Rosero-Bixby, L, Dow, WH. Surprising SES Gradients in Mortality, Health and Biomarkers in a Latin American Population of Adults. J Geront 2009; 64B: 105-117.

14. Viewing VR, Johnston ChH, Lanier JO, Fernandez A, Pandurangi AK. Correlation beteen High Risk Obesity Groups and Low Socioeconomic Status in School Children. South Med Ass 2007; 100 (1): 8-13.

15. Govil SR, Weidner G, Merritt-Worden T, Ornish D. Socioeconomic Status and Impovements in Lifestyle Coronary Risk Factors and Quality of Life: The Multisite Cardiac Lifestyle Intervention Program. Res Pract 2009; 99 (7): 1263-1270.

16. Montague CM. The Physiology of Obesity. ABNF J 2003; 56-59.

17. Yu Z, Nissinen A, Vartiainen E, Song G, Guo Z, Tian H. Changes in cardiovascular risk factors in different socioeconomic groups: seven year trends in a Chinese urban population. J Epidem Comm Health 2000; 54 (9): 692-696.

18. Koziel S, Jankowska EA. Effect of low versus normal birthweight on menarche in 14-year-old Polish girls. J Paediat Child Health 2002; 38 (3): 268-271. 
19. Gaskin PS, Walker SP. Obesity in a cohort of black Jamaican children as estimated by BMI and other indices of adiposity. Eur J Clin Nutr 2003; 57: 420-426.

20. Booth ML, Macaskill P, Lazarus R, Baur LA. Sociodemographic distribution of measures of body fatness among children and adolescetns in New South Wales, Australia. Int J Obesity 1999; 23: 456-462.

21. Rosero-Bixby, L, Dow, WH. Surprising SES Gradients in Mortality, Health and Biomarkers in a Latin American Population of Adults. J Geront 2009; 64B: 105-117.

22. Van Horn LV, Ballew C, Liu K, Ruth K, McDonald A, Hilner J E, Burke GL, Savage PJ, Bragg Ch, Caan B, Jacobs D, Slattery M, Sidney S. Diet, body size, and plasma lipids-lipoproteins in young adults: differences by race and sex. Am J Epid 1998; 133: 9-23.

23. Krajčovičová-Kudláčková M, Blazicek $P$, Spustová V, Valachovicova M, Ginter E. Cardiovascular risk factors in young Gypsy population. Bratisl Lek Listy 2004; 105 (7-8): 256-259.

24. Jurkovičová J, Štefániková Z, Ševčíková L, Sootová L, Ághová L. Vybrané biomarkery zdravotného stavu ako odraz životného štýlu slovenskej populácie. Voj Zdrav Listy 2003; 72 (4): 160-163.
25. Yu Z, Nissinen A, Vartianinen E, Song G, Guo Z, Zheng G, Tuomilehto J, Tian H. Association between socioeconomic status and cardiovascular risk factors in an urban population in China. Bulletin of WHO 2000; 78: 1296-1305.

26. Krajčovičová-Kudláčková M, Blazicek P, Spustová V, Valachovicova M, Ginter E. Cardiovascular risk factors in young Gypsy population. Bratisl Lek Listy 2004; 105 (7-8): 256-259.

27. Chudíková K, Havelková B, Michalovičová M, Rovný I. Hodnotenie výživového stavu obyvatel'ov Slovenskej republiky vo vzt’ahu ku kardiovaskulárnemu riziku. Cardiol 2005, 14 (1): 27-36.

28. Yu Z, Nissinen A, Vartianinen E, Song G, Guo Z, Zheng G, Tuomilehto J, Tian H. Association between socioeconomic status and cardiovascular risk factors in an urban population in China. Bulletin of WHO 2000; 78: 1296-1305.

29. Moayeri H, Bidad K, Aghamohammadi A, Rabbani A, Anari S, Nazemi L, Gholami N, Zadhoush S, Hatmi ZN. Overweight and obesity and their associated factors in adolescents in Teheran, Iran, 2004-2005. Eur J Pedat 2006; 165: 489-493. 